\title{
PENERAPAN MODEL PEMBELAJARAN MID (MEANINGFUL INSTRUCTIONAL DESIGN) BERORIENTASIMIND MAPPING UNTUK MENINGKATKAN PEMAHAMAN KONSEP MATEMATIKA SISWA KELAS VII- C SMP NEGERI 4 SERIRIT
}

\author{
I.G.A.Sekarini ${ }^{1}$, I.N.Suparta ${ }^{2}$, I.W.P.Astawa ${ }^{3}$ \\ Jurusan Pendidikan Matematika, \\ Universitas Pendidikan Ganesha, Singaraja, Indonesia \\ e-mail: ayusekarini918@gmail.com, isuparta@yahoo.com, puja.astawa@undiksha.ac.id
}

\begin{abstract}
Abstrak
Penelitian ini bertujuan untuk mengetahui peningkatan pemahaman konsep matematika siswa melalui penerapan model pembelajaran MID (Meaningful Instructional Design) berorientasi mind mapping pada siswa Kelas VII-C SMP N 4 Seririt. Jenis penelitian ini adalah penelitian tindakan kelas yang terdiri atas tiga siklus, yang setiap siklus terdiri atas tahap perencanaan tindakan, pelaksanaan tindakan, observasi dan evaluasi, serta refleksi. Subjek penelitian ini adalah siswa Kelas VII-C SMP N 4 Seririt sebanyak 30 orang. Data pemahaman konsep matematika dikumpulkan dengan tes uraian. Semua data yang dikumpulkan dianalisis secara deskriptif. Hasil penelitian menunjukkan bahwa rata-rata nilai pemahaman konsep matematika siswa padasetiap siklus mampu mencapai nilai KKM 70. Hasil Siklus I mencapai nilai 70,28, Siklus II mencapai 71,11, dan Siklus III mencapai 75,00. Peningkatan pemahaman konsep matematika siswa terjadi karena model pembelajaran MID berorientasi mind mapping memiliki keunggulan yang pada setiap tahapnya memberikan siswa kesempatan untuk menemukan, memahami dan mengerti konsep matematika yang dipelajarinya. Dengan menyelesaikan berbagai permasalahan yang diberikan pada LKS, siswa juga dilatih untuk kesiapan maupun keaktifannya. Hal tersebut disebabkan karena siswa menggunakan pengalaman dan pengetahuan awalnya untuk menerima, memproses, dan menyimpan suatu konsep sehingga lebih bermakna dalam proses belajar mengajar. $\mathrm{Di}$ mana hal ini berdampak pada peningkatan pemahaman konsep matematika siswa. Selain itu, respon siswa terhadap penerapan model pemebelajaran MID berorientasi mind mapping dalam pembelajaran matematika tergolong positif dengan rata-rata skor respon sebesar 59,60.
\end{abstract}

Kata-kata kunci :Model pembelajaran MID, mind mapping, pemahaman konsep matematika.

\begin{abstract}
This study aims to improve students' on mathematics concepts understanding through the application of Meaningful Instructional Design (MID) model oriented to mind mapping on students of Class VII-C SMP N 4 Seririt. This type of research is a classroom action research consisting of three cycles, each cycle consisting of planning, acting, observing and evaluating, and reflecting. The subjects of this study were 30 students of VII-C class at SMP N 4 Seririt. Data students' of mathematics concepts werecollected by a achiement test. The results showed that the average score of students' mathematics concepts in each cycle has achieved the minimum criteria of mastery learning that in 70 . The results first cycle achieve 70,28, second cycle achieve 71,11, and third cycle achieve 75,00. The increased of students' mathematics concepts isoccuredbecause the MID oriented to mind mapping learning model has some advantages that each of the stage gives students opportunity to discover, comprehend and mathematics concepts that they are studying. By completing various problems given to worksheet, students are also trained for their readiness and activeness. This is because students use their experience and prior knowledge to receive, process, and store more concepts which make the learning process become more meaningful. Thus it has an impact on improving students' of mathematics concepts. In addition, the response of students to the implementation of MID-based learning model oriented to mind mapping in learning mathematics was positive with an average response score of 59.60.
\end{abstract}

Keywords: MID learning model, mind mapping, mathematics concepts. 


\section{Pendahuluan}

Kualitas pendidikan di Indonesia saat ini tergolong rendah. Hal ini dibuktikan dengan data United Nations Development Programme (2015) tentang peringkat Indeks Pengembangan Manusia (Human Development Index), yaitu komposisi dari peringkat pencapaian pendidikan, kesehatan, dan penghasilan per kepala. Indeks Pengembangan Manusia Indonesia pada tahun 2015 sebesar 0,684 dan tahun 1980 yang sebesar 0,474, walaupun terlihat meningkat akan tetapi Indeks Pengembangan Manusia Indonesia masih tergolong sedang, di mana Indonesia berada pada peringkat 113 dari 188 Negara dan indeks pengembangan manusia untuk golongan tinggi adalah 0.746 . Oleh sebab itu, kualitas sumber daya manusia Indonesia masih perlu di tingkatkan. Salah satu cara untuk meningkatkan sumber daya manusia Indonesia adalah dengan cara meningkatkan kualitas pendidikan Indonesia. Dalam membangun dan meningkatkan kualitas pendidikan diperlukan perhatian, penanganan dan prioritas secara intensif baik oleh pemerintah, masyarakat dan pengelola pendidikan khususnya, agar tujuan pendidikan dapat tercapai secara optimal.

Pendidikan di sekolah diperoleh dari proses pembelajaran dimana guru memiliki peran yang penting di dalamnya. Dalam hal ini guru dituntut mampu menciptakan situasi pembelajaran yang kondusif. Bagi seorang guru untuk menciptakan suasana tersebut tentunya tidaklah mudah, ada banyak faktor yang dapat menghambat penciptaan suasana pembelajaran tersebut. Faktor penghambat bisa datang dari siswa yang cenderung pasif dan bahkan bisa datang dari guru sendiri yang kurang inovatif. Sehingga dalam kegiatan pembelajaran cenderung monoton dan menjenuhkan, hal ini akan membuat kegiatan pembelajaran terhadap siswa terasa membosankan. Oleh sebab itu pembelajaran yang aktif, kreatif, inovatif, efektif, dan menyenangkan harus mampu diciptakan dalam kegiatan pembelajaran. Matematika merupakan salah satu mata pelajaran yang dipelajari oleh semua siswa dari Sekolah Dasar, hingga Sekolah Menengah Atas, bahkan di Perguruan tinggi dan memiliki peran yang penting bagi perkembangan ilmu-ilmu yang lain. Selain itu, matematika juga berfungsi sebagai alat dan pola pikir, di mana matematika merupakan salah satu mata pelajaran dengan konsep yang bersifat abstrak. Pada kenyataannya banyak siswa yang kurang berminat terhadap matematika, karena siswa beranggapan bahwa matematika merupakan mata pelajaran yang sulit. Hal ini akan berdampak pada kurangnya penguasaan terhadap konsep-konsep dalam matematika. Jika konsep dasar yang diterima siswa salah, maka sulit untuk memperbaiki kembali terutama jika sudah diterapkan dalam penyelesaian suatu permasalahan, sehingga penting sekali untuk membuat siswa memahami suatu konsep.

Suherman, dkk (2003) menyataan bahwa pemahaman konsep berkenaan dengan pengertian yang memadai tentang sesuatu, berbuat lebih dari pada mengingat, dapat menangkap suatu masalah dan menjelaskan atau menguraikan makna/ide pokok dengan menggunakan konsep yang telah dipahami atau diketahui sebelumnya. Pemahaman konsep matematika merupakan salah satu hal yang terpenting dalam pembelajaran, dimana pemahaman konsep terbentuk bukan hanya dengan jalan mendengarkan penjelasan dari guru, langsung menerima materi dari guru, maupun menghafal rumus-rumus matematika serta langkah-langkah penyelesaian soal yang diberikan, melainkan juga dengan jalan memahami makna dari konsep materi yang dipelajari. Menyadari pentingnya pemahaman konsep dalam pembelajaran matematika, maka pembelajaran tersebut perlu direncanakan sedemikian sehingga pada akhir pembelajaran siswa dapat memahami konsep yang dipelajarinya. Untuk menentukan apakah siswa memiliki pemahaman konsep yang baik dapat dilihat dari indikator kemampuan pemahaman konsep matematika yang terdapat dalam NCTM (National Council of Teacher of Mathematics) (2000:11) yaitu describe concepts in their own words, identify or give examples or non examples of concepts and use concepts correctly in a variety of situations.

Salah satu masalah dalam pembelajaran matematika di sekolah adalah rendahnya kemampuan siswa dalam menemukan dan memahami konsep dari suatu bahasan tertentu. Dalam proses pembelajaran matematika di sekolah, hanya sebagin kecil siswa yang mampu mengerti untuk apa mereka belajar matematika, kebanyakan siswa lainya hanya belajar 
menghafalkan rumus yang ada tanpa memperhitungan untuk apa dan dari mana rumus-rumus yang digunakan itu diperoleh. Siswa yang seperti ini bisaanya hanya akan mementingkan hasil akhir saja tanpa mempertimbangkan proses mendapatkan hasil, biasanya mereka hanya mampu menerapkan rumus-rumus yang ada dibuku ke dalam persoalan, namun tidak memahami apa yang mereka selesaikan.

Kasus seperti ini juga merupakan fenomena yang ditemukan di SMP Negeri 4 Seririt. Pada saat melakukan observasi awal di SMP tersebut dan melakukan wawancara terhadap guru matematika, diperoleh bahwa dalam proses pembelajaran matematika masih banyak ditemui permasalahan. Salah satunya masih banyak siswa yang mengalami kesulitan dalam mengungkapkan kembali dari suatu materi dan kesulitan dalam memahami suatu konsep yang telah diberikan pada setiap materi matematika. Selain itu, peneliti juga melakukan wawancara dengan siswa, siswa mengatakan bahwa matematika adalah mata pelajaran yang terlalu banyak menghafal rumus. Untuk mengetahui atau mengukur sejauh mana pemahaman awal siswa mengenai materi matematika, peneliti melakukan tes awal yang terdiri dari soal uraian terhadap 30 siswa. Nilai KKM (kriteria ketuntasan minimal) matematika Kelas VII di SMP N 4 Seririt adalah 70. Dari tes awal yang dilaksanakan didapat hasil bahwa siswa yang memperoleh nilai lebih dari atau sama dengan nilai KKM hanya 5 orang.

Oleh karena itu pemahaman konsep matematika siswa perlu mendapat perhatian dan jalan keluar yang tepat. Untuk mengatasi permasalahan tersebut, guru diharapkan mampu menerapkan model pembelajaran yang tepat dan sesuai dengan karakteristik siswa, sehingga mampu mendorong siswa untuk meningkatkan kemampuan pemahaman konsep matematika. Salah satu model pembelajaran yang dapat meningkatkan pemahaman konsep matematika siswa adalah model pembelajaran MID (Meaningful Instructional Design).

Model pembelajaran MID merupakan suatu model pembelajaran bermakna dengan cara membuat suatu kerangka kerja. Menurut Suyatno $(2009 ; 67)$ Model pembelajaran MID adalah model pembelajaran yang mengutamakan kebermaknaan belajar dan efektivitas dengan cara membuat kerangka kerja aktivitas secara konseptual kognitif konstrukstivis yang didasari permasalahan kontekstual dan pengalaman siswa. Di mana belajar bermakna merupakan suatu proses dikaitkannya informasi baru pada konsep-konsep relevan yang terdapat dalam struktur kognitif seseorang. Sehingga proses belajar tidak sekedar menghafal konsep-konsep atau fakta-fakta saja, tetapi merupakan kegiatan yang menghubungkan konsep-konsep untuk menghasilkan pemahaman yang utuh dengan lingkungan sekitar siswa sehingga konsep yang dipelajari dapat dipahami secara baik.

Selain model pembelajaran MID, mind mapping yang sering kita sebut dengan peta konsep adalah salah satu cara mencatat materi pelajaran yang memudahkan siswa belajar. Sederhananya mind mapping adalah salah satu teknik mencatat yang mengembangkan gaya belajar visual yang memadukan dan mengembangkan potensi kerja otak yang terdapat di dalam diri seseorang. Untuk membuat mind mapping seseorang biasanya memulainya dengan menulis gagasan utama ditengah halaman dan dari situlah ia bisa membentangkannya keseluruh arah untuk menciptakan semacam diagram yang terdiri dari kata-kata kunci, frasafrasa, konsep-konsep, fakta-fakta, dan gambar-gambar. Mind mapping bisa digunakan untuk membentuk, menvisualisasi, mendesain, mencatat, memecahkan masalah, membuat keputusan, merevisi, dan mengklarifikasi topic utama, sehingga siswa lebih mudah memahami suatu konsep dan siswa bisa mengerjakan tugas-tugas yang banyak sekalipun. Hal ini tentunya memiliki keterkaitan yang sangat erat, di mana jika model pembelajaran MID ini diterapkan dengan berorientasi mind mapping maka akan berpengaruh pada kemampuan pemahaman konsep siswa.

Pada artikel ini dikajibagaimanakah peningkatan pemahaman konsep matematika siswa dan respon siswa Kelas VII-C SMP N 4 Seririt melalui penerapan model pembelajaran MID berorientasi mind mapping pada pembelajaran matematika. 
Jurnal Pendidikan dan Pembelajaran Matematika Indonesia

Vol. 7 No. 1, Tahun 2018

e-ISSN : 2615-7454

\section{Metode Penelitian}

Penelitian ini merupakan penelitian tindakan Kelas (classroom action research) yang bersifat kolaborasi, yang secara umum bertujuan untuk meningkatkan dan memperbaiki kualitas pembelajaran diKelas VII-C SMP N 4 Seririt yang bermuara pada meningkatnya pemahaman konsep Matematika siswa. Tahapan yang dilakukan dalam penelitian tindakan Kelas ini yaitu 1) Perencanaan, 2) Pelaksanaan, 3) Observasi/evaluasi, dan 4) Refleksi. Keterlibatan peneliti dalam pembelajaran dalam bentuk kolaborasi antara peneliti dan guru matematika di SMP N 4 Seririt sehingga memungkinkan terjadinya pemahaman terhadap suatu masalah yang dihadapi.

Subjek dalam penelitian ini adalah semua siswa Kelas VII-C SMP N 4 Seririt semester genap tahun ajaran 2017. Objek penelitian dalam penelitian tindakan Kelas ini adalah pemahaman konsep Matematika siswa Kelas VII-C SMP N 4 Seririt semester genap tahun ajaran 2017 terhadap model pembelajaran MID berorientasi mind mapping. Tindakan ini diberikan terhadap subjek penelitian yang dilakukan dengan 3 siklus. Setiap siklus dilaksanakan selama 4 kali pertemuan, yaitu 3 kali pertemuan untuk pelaksanaan tindakan dan 1 pertemuan untuk melaksanakan tes akhir siklus. Langkah-langkah PTK ini mengacu pada model Kemmis dan Mc.Taggart yang digunakan dalam penelitian ini dapat digambarkan sebagai berikut :

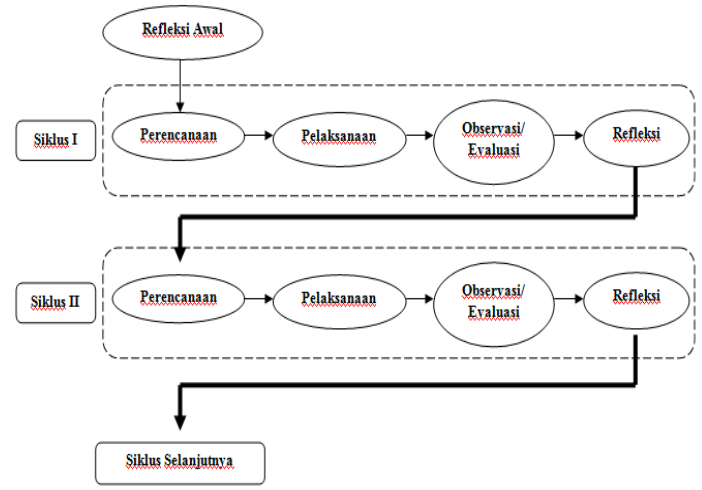

Gambar 1. Langkah-langkah pelaksanaan tindakan Kelas model Kemmis dan Mc.Taggart (dimodifikasi Samsu sumadoyo, 2013:40)

Instrumen yang digunakan dalam penelitian ini adalah berupa tes dan non tes. Tes yang digunakan untuk mengumpulkan data terkait pemahaman konsep matematika siswa adalah tes pemahaman konsep berbentuk uraian. Sedangkan non tes yang digunakan untuk mengumpulkan data terkait respon siswa berbentuk angket. Sebelum digunakan, tes uraian dan angket di uji pakar dengan dua orang dosen Jurusan Pendidikan Matematika Undiksha.

Data pemahaman konsep matematika siswa dikumpulkan dengan tes pemahaman konsep matematika yang dilakukan pada setiap akhir siklus dan data respon siswa dilakukan pada akhir siklus III dengan menggunakan angket.Setelah data pemahaman konsep matematika siswa dan respon siswa terhadap penerapan model pembelajaran MID berorientasi mind mappingdikumpulkan, data selanjutnya dianalisis secara deskriptif, yaitu dengan menghitung rata-rata skor pemahaman konsep matematika siswa. Kriteria ketuntasan pemahaman konsep siswa yang digunakan dinyatakan dalam Tabel 1 dan kriteria penggolongan respon siswa yang digunakan dinyatakan dalam Tabel 2. 
Tabel 1. Kriteria Ketuntasan Pemahaman Konsep Matematika Siswa

\begin{tabular}{|ccc|}
\hline No & $\begin{array}{c}\text { Pemahaman } \\
\text { Konsep } \\
\text { Matematika Siswa }\end{array}$ & Kategori \\
\hline 1. & $70 \leq \bar{M} \leq 100$ & Tuntas \\
\hline 2. & $0 \leq \bar{M}<70$ & Belum Tuntas \\
\hline
\end{tabular}

(Sumber: Arsip SMP Negeri 4 Seririt)

Tabel 2. Kriteria Penggolongan Respon Siswa

\begin{tabular}{|cl|}
\hline Rentang Skor & \multicolumn{1}{c|}{ Kategori } \\
\hline $72 \leq \bar{T}$ & Sangat Positif \\
\hline $54 \leq \bar{T}<72$ & Positif \\
\hline $36 \leq \bar{T}<54$ & Cukup Positif \\
\hline $18 \leq \bar{T}<36$ & Kurang Positif \\
\hline $\bar{T}<18$ & Sangat Kurang \\
\hline (dimodifikasi dari Candiasa, 2010)
\end{tabular}

(dimodifikasi dari Candiasa, 2010)

\section{Hasil Penelitian}

Jurnal Pendidikan dan Pembelajaran Matematika Indonesia | 90 
Data yang sudah dikumpulkan kemudian dianalisis dengan teknik analisis data yang sudah ditetapkan. Dari hasil penelitian yang dilaksanakan, terlihat bahwa pemahaman konsep matematika siswa Kelas VII-C SMP N 4 Seririt mengalami peningkatan dari setiap siklusnya. Kriteria keberhasilan yaitu mencapai nilai KKM $\geq 70$ terjadi pada setiap siklus. Perbandingan data pemahaman konsep matematika siswa selama penelitian berlangsung dengan hasil data tahun ajaran 2015/2016. disajikan pada Gambar 2 berikut

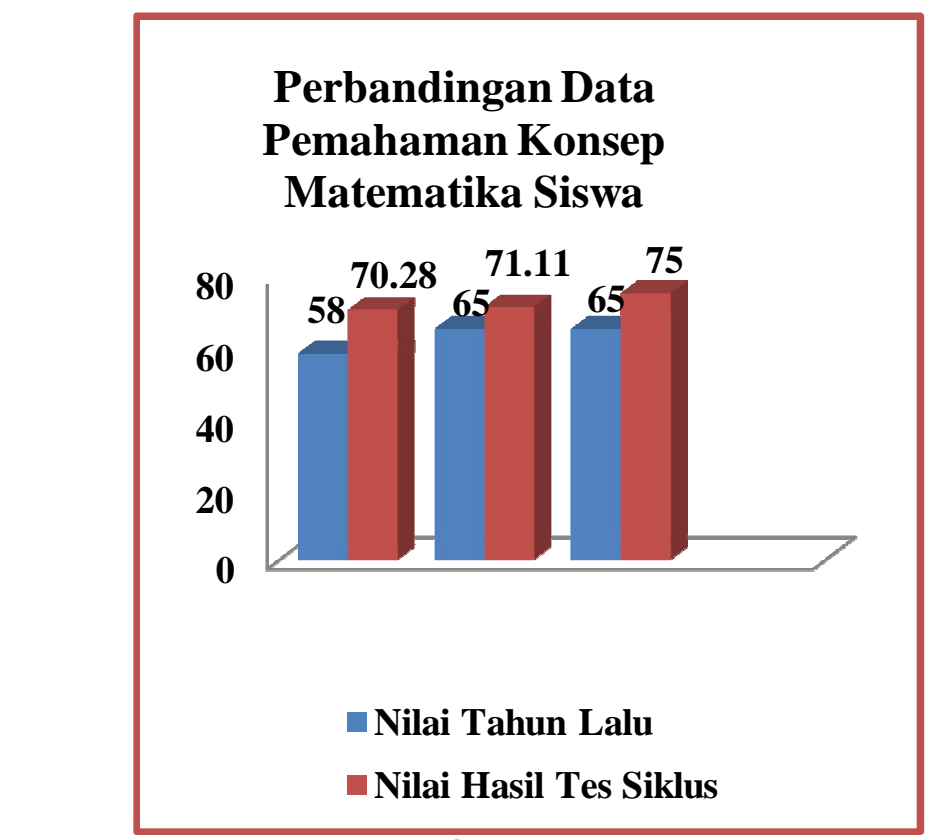

\section{Gambar 2}

Perbandingan Nilai Pemahaman Konsep Matematika Siswa

Selain berdasarkan rata-rata nilai pemahaman konsep matematika siswa yang diketahui, presentase ketuntasan belajar siswa secara klasikal di sajikan pada Gambar 3.

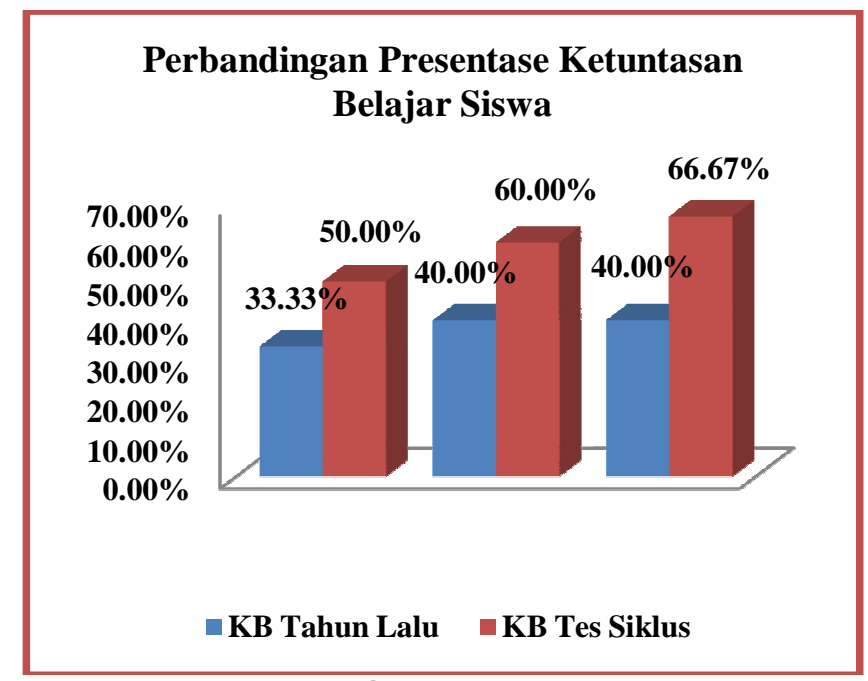

Gambar.3

Perbandingan Presentase Ketuntasan Belajar Siswa 
Berdasarkan hasil data di atas rata-rata nilai tes pemahaman konsep matematika siswa pada siklus I, II, dan III dan presentase ketuntasan belajar siswa secara klasikal menunjukkan bahwa indikator keberhasilan penelitian ini tercapai karena rata-rata nilai pemahaman konsep siswa pada setiap siklus berada di atas 70 dan presentase ketuntasan belajar siswa secara klasikal berada di atas $47 \%$.

Dari kegiatan pembelajaran yang diterapkan, hasil analisis data respon siswa, terlihat bahwa skor terendah adalah 51 dan skor tertinggi adalah 73. Berikut disajikan data respon siswa pada Gambar 4

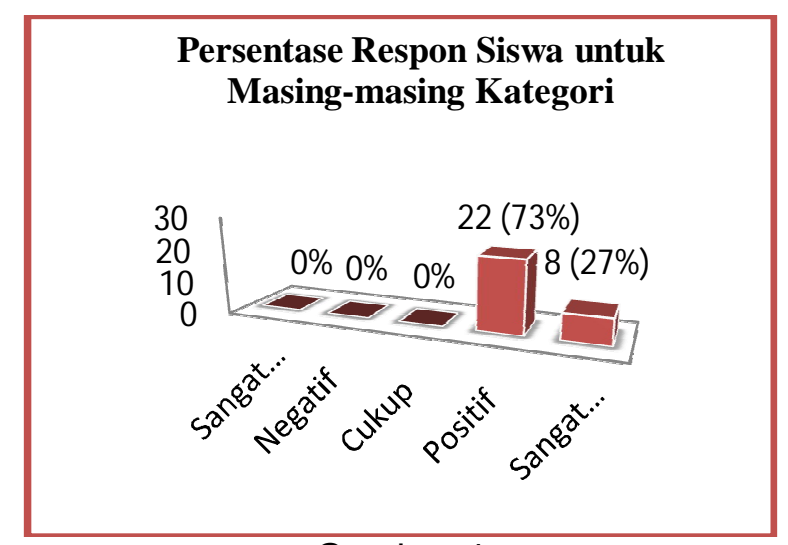

Gambar 4

Persentase Respon Siswa untuk Masing-masing Kategori

Berdasarkan sebaran respon siswa terhadap pembelajaran yang diterapkan, dapat disimpulkan bahwa pembelajaran melalui model pembelajaran MID berorientasi mind mapping mendapatkan respon yang positif dari siswa sesuai dengan kriteria penggolongan respon siswa sehingga respon siswa terhadap model pembelajaran MID berorientasi mind mapping sudah memenuhi kriteria indikator keberhasilan.

\section{Pembahasan}

Berdasarkan hasil penelitian yang telah dilaksanakan dalam tiga siklus terlihat bahwa pemahaman konsep matematika siswa Kelas VII-C SMP N 4 Seririt mengalami peningkatan dari setiap siklus. Hal ini ditinjau dari indikator keberhasilan yang telah terpenuhi dan penerapan model pembelajarn MID berorientasi mind mapping dapat mengatasi permasalahan rendahnya pemahaman konsep matematika siswa pada kelas VII-C.

Peningkatan yang telah dicapai terjadi karena model pembelajaran MID berorientasi mind mapping memiliki keunggulan yang pada setiap tahapnya memberikan siswa kesempatan untuk menemukan, memahami dan mengerti konsep matematika yang dipelajarinya. Dengan menyelesaikan berbagai permasalahan yang diberikan pada LKS, siswa juga dilatih untuk kesiapan maupun keaktifannya. Hal tersebut disebabkan karena siswa menggunakan pengalaman dan pengetahuan awalnya untuk menerima, memproses, dan menyimpan suatu konsep sehingga lebih bermakna dalam proses belajar mengajar.

Secara operasional pembelajaran matematika dengan menggunakan model pembelajaran MID berorientasi mind mapping yang telah diterapkan lebih mengutamakan kebermaknaan belajar, di mana siswa akan lebih mudah mengingat kembali materi-materi yang telah disampaikan ataupun materi yang baru disampaikan. Suatu pembelajaran akan lebih bermakna apabila siswa dapat memperoleh hasilnya sendiri. Pembelajaran MID berorientasi 
mind mapping mampu mendorong siswa untuk meningkatkan pemahaman konsep matematika. Pada model pembelajaran ini siswa diberikan permasalahan dalam LKS oleh guru yang akan siswa selesaikan dengan pengalaman belajarnya dan diminta untuk mencari solusi penyelesaiannya. Setelah mendapatkan solusi penyelesaian hasil tersebut dibuat dalam bentuk mind mapping agar lebih mudah diingat oleh siswa.

Peran guru dalam pembelajaran yang dilakukan adalah sebagai fasilitator dan pembimbing, di mana guru menyediakan kondisi yang kondusif bagi berlangsungnya proses pembelajaran dengan menyajikan permasalahan-permasalahan pada LKS yang menggali pemahaman siswa sehingga muncul pemahaman dalam diri siswa untuk konsep yang sedang dipelajari. Peningkatan pemahaman konsep siswa tidak hanya melalui penerapan model pembelajaran MID berorientasi mind mapping, melainkan juga disebabkan oleh kerja sama yang baik antara guru dan peneliti. Perbaikan yang dilakukan dari hasil refleksi pada siklus I dan II sangat berpengaruh dan mengakibatkan peningkatan pemahaman konsep matematika siswa.

Penelitian oleh Teni Sritresna (2015) dengan artikel ini menggunakan model pembelajaran yang sama. Hal tersebut memperkuat penelitian tersebut dengan menggunakan model pembelajaran MID. Dari hasil yang diperoleh dapat diperlihatkan bahwa model pembelajaran MID berorientasi mind mapping merupakan model pembelajaran yang dapat meningkatkan pemahaman konsep matematika siswa. Adapun kelebihan dari model pembelajaran MID sebagai berikut.

1. Karena model pembelajaran ini lebih mengutamakan kebermaknaan belajar, sehingga model pembelajaran ini efektif untuk diterapkan dalam proses belajar mengajar.

2. Dapat mendorong aktifitas belajar siswa menjadi aktif.

3. Siswa juga lebih mudah menginga..t materi yang disampaikan karena adanya kebermaknaan dalam proses belajar mengajar.

Selain mampu meningkatkan pemahaman konsep matematika siswa, penerapan model pembelajaran MID berorientasi mind mapping juga mendapatkan respon positif dari siswa. Menurut siswa pembelajaran matematika dengan model pembelajaran MID berorientasi mind mapping membuat siswa menjadi tertarik dalam mengerjakan dan terlibat aktif dalam kegiatankegiatan pada permasalahan yang terdapat pada LKS. Selain itu siswa tidak malu lagi mengungkapkan pendapat atau ingin bertanya ketika mengalami kesulitan dalam menyelesaikan masalah yang dihadapi selama proses pembelajaran berlangsung.

Berdasarkan hasil yang diperoleh, secara umum penelitian ini telah mampu menjawab rumusan masalah mengenai peningkatan pemahaman konsep matematika siswa. Penerapan model pembelajaran MID (Meaningful Instructional Design) berorientasi mind mapping dapat meningkatkan pemahaman konsep matematika siswa Kelas VII-C SMP N 4 Seririt. Dengan demikian, dapat dikatakan bahwa penelitian tindakan kelas yang dilaksanakan berhasil.

\section{Kesimpulan Dan Saran} berikut.

Berdasarkan hasil analisis data, temuan dan pembahasan, dapat disimpulkan hal-hal

1) Pemahaman konsep matematika siswa Kelas VII-C SMP N 4 Seririt melalui penerapan model pembelajaran MID berorientasi mind mapping mengalami peningkatan di setiap siklusnya. Peningkatan pemahamn konsep matematika siswa disebabkan karena memiliki keunggulan yang pada setiap tahapnya memberikan siswa kesempatan untuk menemukan, memahami dan mengerti konsep matematika yang dipelajarinya. Dengan menyelesaikan berbagai permasalahan yang diberikan pada LKS, siswa juga dilatih untuk kesiapan maupun keaktifannya. Hal tersebut disebabkan karena siswa menggunakan pengalaman dan pengetahuan awalnya untuk menerima, memproses, dan menyimpan suatu konsep sehingga lebih bermakna dalam proses belajar mengajar. Pembelajaran yang diterapkan membuat siswa memahami konsep dengan 
caranya sendiri melalui penerapan model pembelajaran MID berorientasi mind mapping. Peningkatan pemahaman konsep matematika siswa juga terjadi karena pertanyaan-pertanyaan yang bersifat menggali dan menuntun yang mengarahkan siswa untuk menemukan konsep yang sedang dipelajari. Peningkatan optimal terjadi pada siklus III dan telah memenuhi indikator keberhasilan yang telah ditetapkan.

2) Respon siswa kelas VII-C SMP N 4 Seririt terhadap penerapan model pembelajaran MID berorientasi mind mapping dalam pembelajaran matematika tergolong positif dengan rata-rata skor respon siswa sebesar 59,5.

Berdasarkan hasil penelitian yang diperoleh, adapun saran-saran yang dapat disampaikan yaitu sebagai berikut.

1. Dalam rangka mengoptimalkan proses pembelajaran matematika, diharapkan kepada guru matematika Kelas VII-C SMP N 4 Seririt agar tetap menerapkan model pembelajaran MID berorientasi mind mapping meskipun penelitian ini telah selsesai dilaksanakan. Model pembelajaran MID berorientasi mind mapping dapat dijadikan alternatif untuk mengatasi rendahnya pemahaman konsep matematika siswa.

2. Pembaca yang berminat untuk melaksanakan tindakan lebih lanjut mengenai penerapan model pembelajaran MID berorientasi mind mapping diharapkan agar memperhatikan kendala-kendala yang dialami selama pelaksanaan penelitian sebagai bahan pertimbangan untuk perbaikan dan penyempurnaan pelaksanaan penelitian.

\section{DAFTAR PUSTAKA}

Candiasa, I Made. 2010. Statistik Univariat dan Bivariat Disertai Aplikasi SPSS.Singaraja: Undiksha Press.

NCTM. (2000). Mathematics Assesment a Practical Handbook for gradea 6-8. United States of America : NCTM

Suherman, Erman (dkk). (2003). Strategi Pembelajaran Matematika Kontemporer. Bandung: Jurusan Pendidikan Matematika FMIPA UPI

Sumadayo, Samsu. (2013). Penelitian tindakan Kelas. Yogyakarta: Graha IImu

Suyatno. (2009). Menjelajah Pembelajaran Inovatif. Surabaya: PT Bumi Aksara.

Sritresna, Teni. (2015). Meningkatkan Kemampuan Pemahaman konsep matematika Siswa Melalui Model Pembelajaran Meaningful Instructional Design (MID). Jurnal Pendidikan Matematika. Vol.5, No.1 